\title{
Akut Bronşiolit Olgularında Ortalama Trombosit Hacmindeki Değişikliklerinin Değerlendirilmesi
}

\section{Evaluation of Changes in Mean Platelet Volume in Acute Bronchiolitis Cases}

\author{
Funda KURT ${ }^{1}$, Özlem MUSTAFAOĞLU², Emine Sena ALABOYUN² ${ }^{2}$ Cüneyt GÜRSOY ${ }^{1}$, \\ Halil ibrahim YAKUT1 ${ }^{1}$ Emine DIBEK MISIRLIOĞLU1
}

${ }^{1}$ Ankara Şehir Hastanesi, Çocuk Acil Kliniği, Ankara, Türkiye

${ }^{2}$ Ankara Çocuk Sağlığı ve Hastalıkları Hematoloji Onkoloji Eğitim Araştırma Hastanesi, Çocuk Kliniği, Ankara, Türkiye

\section{Öz}

Amaç: Akut bronşiolit, iki yaşından küçük çocuklarda sıklıkla viral etkenlerin neden olduğu, akut solunum hastalığıdır. Akut bronşiolit döneminde inflamasyon ile birlikte ortalama trombosit hacminde (MPV) artış olabilmektedir. Bu çalışmada, hastanemiz acil servisinde akut bronşiolit tanısı alan olguların klinik, laboratuvar ve tedavi özelliklerinin incelenmesi ayrıca bronşiolit dönemi ile sağlıklı dönemdeki MPV değerlerinin karşılaştıııması amaçlanmıştır.

Gereç ve Yöntemler: Çocuk acil servisine 01.01.2015- 12.12.2017 tarihleri arasında akut bronşiolit tanısı alan olgular geriye dönük olarak değerlendirildi.

Bulgular: Çalışmaya alınan 314 olgunun ortanca yaşı (IQR), 14.0 (7.0-20.0 ay) olup, 199'u (\%63.4) erkek cinsiyetteydi. Başvuruda en sık şikayetlerin 298 (\%94.9) öksürük, 196 (\%62.4) burun akıntısı ve 107 (\%34.1) ateş olduğu saptandı. En sık fizik muayene bulguları sırasıyla wheezing (\%58.3), retraksiyon (\%46.2) ve ral (29.3)'di. Olguların 132'si (\%42.0) ilk bronșiolit atağı ile bașvurmuștu, 182'sinin (\%58.0) tekrarlayan bronșioliti vardı. Tekrarlayan bronșioliti olan olgularda ortanca atak sayısı 2'di. Ortalama ilk atak yaşının 6.92 3.81 ay (1-19 ay) olduğu saptandı. Olguların 137'si (\%43.6) hafif, 121'i (38.5) orta, 56'sı (17.9) ağır atak olarak değerlendirildi; 182'si (\% 58.0) acilden taburcu edildi, 1 tanesi sevk edidi, 131'i (\%41.7) yatırlarak izlendi. Bronşiolit ve sağlıklı dönemdeki platelet $\left(/ \mathrm{mm}^{3}\right)$ ve MPV (fl) (ortanca, minimummaksimum) değerleri sırasıyla 129.6 (110.0- 1140.0); 349.9 (131.0- 967.0) ve 7.7 (6.1-12.1); 7.7 (5.6-11.2)'di. Bronşiolit ve sağlıklı dönemdeki platelet ve MPV değerleri arasında fark saptanmadı (sırasıyla $p=0.655, p=0.855$ ).

Sonuç: Bronşiolit tanısı öykü ve fizik muayene bulgularıyla konulur, hastalık şiddetinin belirlenmesinde MPV değerinin bir Önemi saptanmamıştır.

Anahtar Sözcükler: Acil servis, Bronşiolit, Çocuk, Ortalama trombosit hacmi

\section{ABSTRACT}

Objective: Acute bronchiolitis is an acute respiratory tract disease often caused by viral factors in children younger than two years. In the acute bronchiolitis period, there may be an increase in the mean platelet volume (MPV) due to inflammation. This study is organized to investigate the clinical, laboratory and treatment characteristics of patients diagnosed with acute bronchiolitis in the emergency department of our hospital and to compare the MPV values of these patients during the illness and the healthy period.

\section{(1)}

KURTF

MUSTAFAOĞLU Ö

ALABOYUNES

GÜRSOY C

$\begin{array}{lll}\text { YAKUT HI } & : 0000-0001-6946-4995 \\ \text { DIBEK MISIRLIOĞLU E : 0000-0002-3241-2005 }\end{array}$

: 0000-0002-3485-7200 Etik Kurul Onayı / Ethics Committee Approval: Bu çalsşmada ulusal ve uluslararası etik kurallara uyulmuştur. Çalışma için, Ankara Çocuk Sağlığı ve : 0000-0001-8915-6922 Hastalıkları Hematoloji Onkoloji SUAM, Klinik Araşıırmalar Etik Kurulu'ndan (toplantı tarihi: 27.02.2017, karar no: 2017-001) izin alındı. Kayıt sırasında veliler 0000-0001-8637-5695 tarafından araştırmaya katıım için bilgilendirilmiş bir onay imzalanmıștır.

0000-0001-6946-4995 Yazarların katkısı / Contribution of the Authors: KURT F: Araștırma ve/veya makalenin hipotezini veya fikrini olușturan, Sonuçlara ulașmak için planlama/ 0000-0002-3241-2005 metodoloji belirleme, Araştırma/çalısmanın sorumluluğunu üstlenmek, ilerlemenin seyrini denetlemek, Hasta takibinde sorumluluk almak, ilgili biyolojik malzemelerin toplanması, veri yönetimi ve raporlama, deneylerin yürütülmesi, Yazım ve dilbilgisi dıșnnda bilimsel olarak gönderilmeden önce makaleyi gözden geçirme, MUSTAFAOĞLU Ö: Hasta takibinde sorumluluk almak, ilgili biyolojik malzemelerin toplanması, veri yönetimi ve raporlama, deneylerin yürütülmesi, ALABOYUN ES: Hasta takibinde sorumluluk almak, ilgili biyolojik malzemelerin toplanması, veri yönetimi ve raporlama, deneylerin yürütülmesi, GÜRSOY C: Hasta takibinde sorumluluk almak, ilgili biyolojik malzemelerin toplanması, veri yönetimi ve raporlama, deneylerin yürütülmesi, YAKUT Hi: Yazım ve dilbilgis dıșında bilimsel olarak gönderilmeden önce makaleyi gözden gecirme, DiBEK MISIRLIOGLU E: Araștırma ve/veya makalenin hipotezini veya fikrini olușturan, Sonuçlara ulașmak için planlama/metodoloji belirleme, Araștırma/çalıșmanın sorumluluğunu üstlenmek, ilerlemenin seyrini denetlemek, Yazım ve dilbilgisi dıșında bilimsel olarak gönderilmeden önce makaleyi gözden geçirme

Atıf yazım şekli / How to cite : Kurt F, Mustafaoğlu Ö, Alaboyun ES, Gürsoy C, Yakut Hí, Dibek Mısırlığlu E. Akut Bronşiolit Olgularında Ortalama Trombosit Hacmindeki Değişikliklerinin Değerlendirilmesi. Türkiye Çocuk Hast Derg 2020;14:352-358.
Yazışma Adresi / Correspondence Address:

Funda KURT

Ankara Șehir Hastanesi, Çocuk Acil Kliniği, Ankara, Türkiye

E-posta: drfundakurt@gmail.com
Geliş tarihi / Received : 25.04.2020 Kabul tarihi / Accepted : 15.06.2020 Elektronik yayın tarihi $\quad: 19.06 .2020$ Online published

DOI: 10.12956/tchd.726711 
Material and Methods: Patients presenting to the pediatric emergency department of our hospital with acute bronchiolitis between 01.01.2015 and 12.12.2017 were evaluated retrospectively.

Results: The median age (IQR) of the 314 patients was 14.0 (7.0-20.0 months) and 199 (63.4\%) patients were male. The most common complaints in the admission were cough (94.9\%), rhinorrhea (62.4\%) and fever (34.1\%). The most common physical examination findings were wheezing (58.3\%), retraction (46.2\%) and ral (29.3), respectively. Of those, 132 (42.0\%) patients applied with the first bronchiolitis attack and 182 (58.0\%) had recurrent bronchiolitis. The median attack number was 2 in patients admitted with recurrent bronchiolitis. The mean age of first attack was $6.92 \pm 3.81$ months (1- 19 months). 137 (43.6\%) patients were considered as mild, 121 (38.5) were moderate, 56 (17.9) were considered as severe attacks. 182 (58.0\%) of the cases were discharged from the emergency, one was referred to another hospital, and 131 (41.7\%) patients were hospitalized. Platelet (/ mm $\mathrm{mm}^{3}$ ) and MPV (fl) (median, minimum-maximum) values in bronchiolitis and healthy period are 129.6 (110.0-1140.0); 349.9 (131.0-967.0) and 7.7 (6.1- 12.1); 7.7 (5.6-11.2) respectively. There were no differences between platelet and MPV values in the healthy period and bronchiolitis period $(p=0.655, p=0.855$, respectively).

Conclusion: Acute bronchiolitis is mild in most cases and can be treated at home with supportive care. The diagnosis of the disease is made with history and physical examination findings. An importance of MPV value was not determined in detecting the severity of the disease.

Key Words: Emergency service, Bronchiolitis, Child, MPV

\section{GiRiş}

Akut bronşiyolit sıklıkla viral enfeksiyonun neden olduğu alt solunum yolu hastalığıdır ve en sık iki yaşından küçük çocuklarda görülür (1-3). Respiratuvar sinsityal virus (RSV) bronşiolite en sık neden olan virüstür. Bir yaşından küçük çocuklarda etken çoğunlukla RSV olmakla birlikte, daha büyük çocuklarda parainfluenza, adenovirüs, insan metapnömovirüs, influenza ve rinovirüs gibi diğer viral patojenler de etken olarak görülebilmektedir (1, 4).

Akut bronşiyolit tanısı öykü ve fizik muayene bulgularıyla konulur, Bronşiolit olan çocuklar tipik olarak 2-4 gün düşük dereceli ateş, burun akıntısı ve tıkanıklığı sonrasında hafif solunum yolu hastalığı semptomları (öksürük, wheezing, takipne ve solunum çabasında artış) ile başvururlar (4, 5). Fizik muayenede solunum sayısı artmıştır, taşikardi vardır. Dinlemekle akciğerlerde ronküsler ve raller duyulabilir. Ağır olgularda siyanoz ve apne görülebilir (6).

Trombositler, anjiogenezis, inflamasyon, alerjik reaksiyonlar, dokuların tamir ve yenilenmesinde önemli rol oynayan hücrelerdir. İnflamatuvar, enfeksiyöz ve alerjik hastalıklarda ortalama trombosit hacminin (MPV) değiştiği bilinmektedir (7). Bazı çalışmamalarda artmış, bazılarında ise azalmış MPV değerinin inflamatuar bir belirteç olarak kullanılabileceği bildirilmiştir (8-11). Akut bronşiolit sırasındaki MPV değişikliğini gösteren az sayıda çalışma vardır.

Bu çalışmada, hastanemiz acil servisinde akut bronşiolit tanısı alan olguların klinik, laboratuvar ve tedavi özelliklerinin incelenmesi ayrıca bronşiolit dönemi ile sağlıklı dönemdeki MPV değerlerinin karşılaştıııması planlanmıştır.

\section{GEREÇ ve YÖNTEMLER}

Hastanemiz üçüncü basamak bir çocuk hastanesi olup yıllık yaklaşık 140000 hastaya hizmet vermektedir. Bu çalışmaya 1.1.2015- 12.12.2017 tarihleri arasında çocuk acil kliniğimizde Uluslararası Hastalık Sınıflaması Versiyon 10 (ICD-10) kodlama sistemine göre "J21- Akut bronşiolit" kodunu almış olan, 2 yaş altındaki olgular dahil edildi. Bu tarihler arasında J21 tanı kodlu 2390 olgu olduğu belirlendi. Yanlış tanı kodu girilmiş (2186), eksik bilgileri ve sağlıklı dönemde hemogram değeri olmayan (204) olgular çalışmaya dahil edilmedi.

İki yaşından küçük çocuklarda, viral üst solunum yolu enfeksiyonu sonrasında göğüs retraksiyonu, takipne, wheezing ya da ral bulgularından en az ikisinin olması akut bronşiolit olarak tanımlanmıştır (12).

Olguların yaşı, cinsiyeti, başvuru şikayetleri, fizik muayene bulguları, vital bulgular, ilk atak mı tekrarlayan bronşiolit mi olduğu, acilde verilen tedaviler, hangi tetkiklerin istendiği, yatış yapııp yapılmadığı, eğer yatırılarak izlenmiş ise hangi servise yatış yapıldığı ve yatış süresi (saat) hasta dosyalarından geriye dönük olarak incelendi.

Olgular, apne, retraksiyon, siyanozun varlığına; nabız, solunum sayısına ve oksijen saturasyon düzeyine göre hafif, orta ve ağır bronşiolit atağı olarak üç gruba ayrıldı. Başvuru sırasında retraksiyonu hafif, siyanozu ve apnesi olmayan, solunum sayısı 50/dk'nın nabzı 140/dk'nın altında olan, saturasyonu \%93'ün üzerinde olan hastalar hafif; apnesi olmayan ve çekilmeleri orta derecede olan, solunum sayısı 50-70/dk, nabızı 140-160/dk, saturasyonu \% 86-92 arasında olanlar orta; apnesi ve siyanozu olan, çekilmeleri ağır olan, solunum sayısı 70/dk'nın, nabzı 160/ dk'nın üzerinde, saturasyonu \%85'in altında olan hastalar ağır grupta değerlendirildi. Olgular saptanan en ağır kriterin uyduğu ağılık derecesinde kabul edildi (6).

Başvuru şikayetleri, öksürük, burun akıntısı, ateş, hırıtı ve diğer; fizik muayene bulguları, wheezing, ral, retraksiyon, siyanoz, apne olarak gruplandırıldı.

Başvuruda Posteroanterior (PA) akciğer grafisi ve C-Reaktif Protein (CRP) tetkiklerinin bakılıp bakılmadığı; sağlıklı dönemde ve bronşiolit döneminde bakılmış olan beyaz küre, eozinofil, platelet ve MPV değerleri kaydedildi.

Tekrarlayan atak olan olgularda yalnızca çalışma dönemindeki atak değerlendirmeye alındı.

Çalışma için hastanemiz Etik Kurulu'ndan (toplantı tarihi: 27.02.2017, karar no: 2017-001) izin alındı. 


\section{İstatistiksel Analiz}

İstatistiksel değerlendirmede IBM SPSS Statistics 22.0 (SPSS Inc., Chicago, IL, ABD) programı kullanıldı. Kesikli değişkenler sayı/yüzde, sürekli değişkenler ortalama, ortanca, minumum maksimum olarak verildi. Verilerin normal dağılıp dağılmadığı Kolmogrov-Simirnov testi yapılarak belirlendi. İki ve daha fazla grubun kesikli değişkenlerinin karşılaştııımasında Ki-kare testi, sürekli değişkenlerin karşılaştııımasında Mann Whitney $U$ testi kullanıldı. Sürekli değişkenleri tekrarlı ölçümünde Wilcoxon testi kullanıldı. $p<0.05$ anlamlılık sınırı kabul edildi.

\section{BULGULAR}

Olguların ortanca yaşı ÇDA (Çeyrek değerler aralığı), 14.0 (7.0-20.0) ay olup, 199'u (\%63.4) erkek, 115'i (\%36.6) kız cinsiyetteydi. Olguların 145'i (\%46.2) bir yaşından küçüktü. En sık başvuru şikayetleri sırasıyla öksürük 298 (\%94.9), burun akıntısı 196 (\%62.4) ve ateş 107 (\%34.1); fizik muayene bulguları sırasıyla wheezing 183 (\%58.3), retraksiyon 145 (\%46.2) ve ral 92 (\%29.3)'di. Olgularının çoğunun (\%43.6) hafif atak ile başvurduğu, 182'sinin (\%58.0) acil servisden taburcu edildiği belirlendi. Olguların 313'üne (\%99.7) salbutamol, 252'sine (\% 80.3) sistemik steroid verilmişti; 131'i (\%41.7) hastaneye yatırlarak izlenmişti (Tablo I).

Acil servis yatış süresi ortalama $\pm \mathrm{SD}$ (minimum-maksimum) $29.2 \pm 18.8$ (1-72) saatteydi. Süt çocuğu ve yoğun bakım yatış süreleri sırasıyla ortalama $\pm S D$ (minimum-maksimum): $5.76 \pm$ 2.3 (1-17) gün; $3.5 \pm 1.7$ (1-5) gündü.

Olguların 132'sinin (\% 42.0) ilk bronşiolit atağı, 182'sinin (\% 58.0) tekrarlayan bronşiolit atakları olduğu saptandı. İlk ve tekrarlayan bronşiolit atağı olan olgularda: erkek cinsiyet

Tablo I: Olguların demografik ve klinik özellikleri.

\begin{tabular}{|c|c|c|}
\hline & $\mathbf{n}$ & (\%) \\
\hline $\begin{array}{c}\text { Yaş (ay)* }^{*} \\
0-11.9 \\
12-24\end{array}$ & $\begin{array}{c}14.0(7.0-20.0) \\
145 \\
169\end{array}$ & $\begin{array}{l}(46.2) \\
(53.8)\end{array}$ \\
\hline $\begin{array}{l}\text { Cinsiyet } \\
\text { Erkek } \\
\text { KIZ }\end{array}$ & $\begin{array}{l}199 \\
115\end{array}$ & $\begin{array}{l}(63.4) \\
(36.6)\end{array}$ \\
\hline $\begin{array}{l}\text { Başvuru şikayetleri } \\
\text { Öksürük } \\
\text { Burun akıntısı } \\
\text { Ateş } \\
\text { Hırıltı } \\
\text { Diğer }\end{array}$ & $\begin{array}{r}298 \\
196 \\
107 \\
37 \\
65\end{array}$ & $\begin{array}{l}(94.9) \\
(62.4) \\
(34.1) \\
(11.8) \\
(20.7)\end{array}$ \\
\hline $\begin{array}{l}\text { Fizik muayene bulgu } \\
\text { Wheezing } \\
\text { Retraksiyon } \\
\text { Ral } \\
\text { Siyanoz } \\
\text { Apne }\end{array}$ & $\begin{array}{c}183 \\
145 \\
92 \\
5 \\
4\end{array}$ & $\begin{array}{l}(58.3) \\
(46.2) \\
(29.3) \\
(1.6) \\
(1.3)\end{array}$ \\
\hline İlk atak yaşıๆ & $6.92 \pm 3.81$ ay ( $1-19$ ay) & \\
\hline $\begin{array}{l}\text { Atak şiddeti } \\
\text { Hafif atak } \\
\text { Orta atak } \\
\text { Ağır atak }\end{array}$ & $\begin{array}{c}137 \\
121 \\
56\end{array}$ & $\begin{array}{l}(43.6) \\
(38.5) \\
(17.9)\end{array}$ \\
\hline $\begin{array}{l}\text { Acilde verilen tedavil } \\
\text { Oksijen } \\
\text { Salbutamol } \\
\text { Steroid } \\
\text { Ipratropium bromür } \\
\text { Adrenalin }\end{array}$ & $\begin{array}{c}298 \\
313 \\
252 \\
98 \\
33\end{array}$ & $\begin{array}{l}(94.9) \\
(99.7) \\
(80.3) \\
(31.2) \\
(11.5)\end{array}$ \\
\hline $\begin{array}{l}\text { Sonuç } \\
\text { Acilden taburcu } \\
\text { Hastaneye yatış } \\
\text { Acil servis } \\
\text { Süt çocuğu servisi } \\
\text { Yoğun bakım }\end{array}$ & $\begin{array}{c}182 \\
131 \\
36 \\
90 \\
5\end{array}$ & $\begin{array}{l}(58.0) \\
(41.7) \\
(27.5) \\
(68.7) \\
(3.8)\end{array}$ \\
\hline Sevk & 1 & $(0.3)$ \\
\hline
\end{tabular}

* ortanca (ÇDA: çeyrek değerler aralığı)," ortalama \pm SD (minimum-maksimum) 
Tablo II: IIk ve tekrarlayan bronşiolit olgularının karşılaştıııması.

\begin{tabular}{|c|c|c|c|}
\hline & $\begin{array}{l}\text { İlk Bronşiolit } \\
\text { n (\%) }\end{array}$ & $\begin{array}{c}\text { Tekrarlayan bronşiolit } \\
\text { n (\%) }\end{array}$ & $p$ \\
\hline $\begin{array}{l}\text { Cinsiyet } \\
\text { Erkek } \\
\text { KIz }\end{array}$ & $\begin{array}{l}72(54.5) \\
60(45.5)\end{array}$ & $\begin{array}{r}127(69.8) \\
55(30.2)\end{array}$ & $0.006^{*}$ \\
\hline $\begin{array}{l}\text { Fizik muayene bulgu } \\
\text { Wheezing } \\
\text { Retraksiyon } \\
\text { Ral } \\
\text { Siyanoz } \\
\text { Apne }\end{array}$ & $\begin{array}{c}53(40.2) \\
49(37.1) \\
47(35.6) \\
4(3.0) \\
2(1.5)\end{array}$ & $\begin{array}{c}130(71.4) \\
96(52.7) \\
45(24.7) \\
1(0.5) \\
2(1.1)\end{array}$ & $\begin{array}{r}<0.001^{*} \\
0.021^{*} \\
0.044^{*} \\
0.166^{*} \\
1.000^{*}\end{array}$ \\
\hline Solunum sayısı" & $51.1 \pm 10.0(28-80)$ & $50.7 \pm 9.8(28-80)$ & $0.963^{* *}$ \\
\hline $\begin{array}{l}\text { Atak şiddeti } \\
\text { Hafif atak } \\
\text { Orta atak } \\
\text { Ağır atak }\end{array}$ & $\begin{array}{l}70(53.0) \\
48(36.4) \\
14(10.6)\end{array}$ & $\begin{array}{l}83(45.6) \\
73(40.1) \\
26(14.3)\end{array}$ & $0.376^{*}$ \\
\hline $\begin{array}{l}\text { Acilde verilen tedavi } \\
\text { Salbutamol } \\
\text { Steroid } \\
\text { Ipratropium bromür } \\
\text { Adrenalin }\end{array}$ & $\begin{array}{r}130(98.5) \\
95(72.0) \\
29(22.0) \\
4(3.0)\end{array}$ & $\begin{array}{c}182(100.0) \\
154(84.6) \\
64(35.2) \\
29(15.9)\end{array}$ & $\begin{array}{r}0.176^{*} \\
0.007^{*} \\
0.012^{*} \\
<0.001^{*}\end{array}$ \\
\hline $\begin{array}{l}\text { Yapılan tetkikler } \\
\text { Hemogram } \\
\text { CRP } \\
\text { Akciğer grafisi }\end{array}$ & $\begin{array}{l}92(69.7) \\
83(62.9) \\
96(72.7)\end{array}$ & $\begin{array}{l}146(80.2) \\
126(69.2) \\
146(80.2)\end{array}$ & $\begin{array}{l}0.034^{*} \\
0.276^{*} \\
0.135\end{array}$ \\
\hline $\begin{array}{l}\text { Sonuç } \\
\text { Acilden taburcu } \\
\text { Hastaneye yatış } \\
\text { Acil servis } \\
\text { Süt çocuğu servisi } \\
\text { Yoğun bakım }\end{array}$ & $\begin{array}{c}83(62.9) \\
49(37.1) \\
10(20.4) \\
36(73.5) \\
3(6.1)\end{array}$ & $\begin{array}{c}99(54.4) \\
82(45.1) \\
26(31.7) \\
54(65.9) \\
2(2.4)\end{array}$ & $0.165^{*}$ \\
\hline Sevk & & $1(0.5)$ & \\
\hline
\end{tabular}

"ortalama $\mathrm{SD}$ (minimum-maksimum), * Chi-square Test, ** Mann-Whitney $\cup$ Test, Sütun yüzdesi verilmiştir.

Tablo III: Olguların bronşiolit ve sağlıklı dönemlerindeki laboratuvar değerlerinin karşılaştırıması.

\begin{tabular}{l|c|c|c}
\hline & Bronşiolit dönemi & Sağlıklı dönem & p \\
\hline Beyaz küre $\left(\mathbf{m m}^{3}\right)^{*}$ & $11.3(3.9-28.6)$ & $9.3(5.1-16.5)$ & 0.001 \\
\hline Eozinofil (\%)* & $0.7(0.1-18.9)$ & $2.2(0.1-13.1)$ & 0.001 \\
\hline Platelet $\left(/ \mathbf{m m}^{3}\right)^{*}$ & $319.0(131.0-793.0)$ & $328.0(131.0-690.0)$ & 0.655 \\
\hline MPV (fl)* & $7.7(6.1-12.7)$ & $77(5.9-11.2)$ & 0.855 \\
\hline
\end{tabular}

* (ortanca, minimum-maksimum)

oranının sırasıyla \% 54.5 ve \% 69.8 olduğu saptandı, tekrarlayan bronșiolit olgularında erkek cinsiyet daha fazlaydı $(p=0.006)$. Illk ve tekrarlayan bronșiolit atağı olan olgularda wheezing ve retraksiyon oranları sırasıly \% 40.2 ve \% 71.4 ; \% 37.1 ve 52.7 'di. Tekrarlayan bronşiolit olgularında wheezing ve retraksiyon oranı daha fazlaydı (sırasıyla $<0.001, p=0.021$ ). Tekrarlayan bronşiolit olgularında acil servisde steroid, ipratropium bromür, adrenalin tedavilerinin daha fazla verildiği belirlendi (sırasıyla $p=0.007, p=$ 0.012, $p<0.001$ ) (Tablo II). Illk ve tekrarlayan atağı olan olgular arasında atak şiddeti arasında fark saptanmadı $(p=0.376)$

Olguların 137'si (\%43.6) hafif, 121'i (38.5) orta, 56’sı (17.9) ağır atak olarak değerlendirilmişti. Hafif, orta ve ağır atak olarak değerlendirilen olguların yatıș oranları sırasıyla 28 (\%20,4), 67 (\%55.3); 47( \%83.9)'di. Hafif atak olan olguların 121'i (\%88.3) ayaktan izlendi; 11 'i acil servise (\%8.0), 5’i (\%3.7) servisde takip edildi.

Olguların 177'si (\%56.4) orta ve ağır şiddetteydi. Orta atak olarak değerlendirilen olguların sistemik steroid ve ipratropium bromür alma oranı sırasıyla \%95.9 ve \%33.1'di. Ağır atak olarak değerlendirilen olguların sistemik steroid ve ipratropium bromür alma oranı sırasıyla \%100 ve 53.6'di (sırasıyla $p<00.1$, $p<0.001$ ). Sistemik steroid ve ipratropium bromid orta/ağır bronșiolit olan olgularda daha fazla uygulanmıştı. 
Olguların 238'ine (\%75.6) tam kan sayımı, 209'una (\%66.3) CRP tetkiki istenmiş ve 242'sine (\%76.8) PA akciğer grafisi çekilmişti. Tekrarlayan bronşiolit ve ilk atağı olan olgularda PA akciğer grafisi, hemogram ve CRP bakılma oranları sırasıyla \%80.2, \%72.7; \%80.2, 69.7; \%69.2, \%62.9'du. Tekrarlayan bronşiolit olgularında daha fazla hemogram istenmişti (sırasıyla $p=0.135, p=0.034, p=0.276)$.

Hafif, orta ve ağır atağı olan olgularda (PA) akciğer grafisi, hemogram ve CRP bakılma oranları sırasıyla \%62.7, \%88.4, \% 97.5; \%60.1, \%87.6, \%100; \%51.0, \%78.5, 90.0'dı. Orta -ağır atak olan olgularda daha fazla tetkik istendiği saptandı (sırasıyla $p<0.001, p<0.001, p<0.001)$.

Sağlıklı dönemde bronşiolit sırasında beyaz küre ortanca değerlerinin sırasıyla $12.2\left(/ \mathrm{mm}^{3}\right)$ ve $9,7\left(/ \mathrm{mm}^{3}\right)$; eozinofil ortanca değerlerinin 1.5 (\%) ve 3.0 (\%) olduğu saptandı. Sağlıklı dönem ile karşılaştırıldığında, bronşiolit sırasında beyaz kürenin daha yüksek ve eozinofil sayısının daha düşük olduğu görüldü (sırasıyla $p=0.001, p=0.001)$. Sağlıklı dönem ile bronşiolit dönemindeki platelet ve MPV değerleri arasında fark saptanmadı (sırasıyla $\mathrm{p}=$ 0.655, p=0.855) (Tablo III).

Illk ve tekrarlayan bronşiolit olgularında bronşiolit döneminde bakılmış beyaz küre, eozinofil ve MPV değerleri arasında fark saptanmadı (sırasıyla $p=0.928, p=0.342, p=0.445$ ). Tekrarlayan atak olgularında sağlıklı dönemdeki eozinofil ortancası daha yüksekti $(0.7 ; 2.2)(p<0.001)$.

Atak şiddetine göre eozinofil, platelet ve MPV değerleri arasında fark saptanmadı (sırasıyla $p=0.765, p=0.760, p=0.268$ ). Hafif atak olgularında ortalama beyaz küre $\left(/ \mathrm{mm}^{3}\right)$ sayısının daha düşük olduğu saptandı) (sırasıyla 9.5; 18.6) ( $p=0.003)$.

\section{TARTIŞMA}

Akut bronşiolit, acil servislere başvurunun ve hastane yatışlarının en sık nedenlerindendir. Çalışmamızda olguların çoğunun erkek cinsiyette olduğu; öksürük, burun akıntısı ve ateşin en sık görülen semptomlar olduğu saptandı. Tekrarlayan atak olgularında sağlıklı dönemdeki eozinofil ortancasının daha yüksek olduğu belirlendi. Sağlıklı dönem ile bronşiolit dönemindeki MPV değerleri arasında fark saptanmadı.

İki yaşına kadar olan çocukların çoğu RSV ve diğer bronşiolit etken patojenleri ile enfekte olurlar $(2,3)$. Erkek çocuklar RSV bronşiolitinden kızlara göre daha sık etkilenirler, erkek/kı oranı yaklaşık 1.5/1'dir (13). Çalışmalarda akut bronşiolit olgularında erkek cinsiyetin daha fazla olduğu rapor edilmiştir. Akut bronşiolit ile ilgili meta-analizde, Kanada, Avustralya ve Yeni Zellenda'da olguların \%62'sinin erkek cinsiyette olduğu bildirilmiştir ( (3, 1418). Çalışmamızda da literatür ile benzer şekilde akut bronşiolit olgularının \%63.4'ünü erkekler oluşturdu.

Akut Bronşiolit, üst solunum yolu enfeksiyonu bulguları ile başlayıp sonrasında öksürük, hışıltı ve solunum sıkıntısı bulguları olur. Kanık ve ark.'nın (16) çalışmasında bronşiolit olgularının \%31'inde ateşin eşlik etttiği saptanmıştır. Ergin ve ark.'nın (19) çalışmasında öksürük ve ateş şikayetlerinin en sık görülen şikayetler olduğu saptanmıştır. Literatüre benzer şekilde çalışmamızda hastaların en sık başvuru şikayetinin öksürük olduğu, burun akıntısı ve ateşin sık görülen yakınmalar olduğu saptandı.

A.bronşiolit tedavisinde hastalık şiddetinin belirlenmesi, SIVı ve oksijen ihtiyacının sağlanması gerekmektedir. Bronşiolit tedavisinde NICE (National Institute for Health and Care Excellence), AAP (Amerikan Pediatri Akademisi) ve CPS (Kanada Pediatri Derneği) önerileri benzerdir. Bu önerilere göre bebek ve çocuklarda akut bronşiolit tedavisi destekleyici bakımdır (5, 12, 20-22). Klinik semptom skorlarında kısa süreli iyileşme görülmesine rağmen, hastaneye yatış gereksinimi, oksijen satürasyonu, hastanede kalış süresinde ve hastalığın iyileşmesinde etkisi saptanmadığı için bronkodilatör kullanımı önerilmemektedir (2, 5, 20). Ayrıca epinefrin ve sistemik/ inhale kortikosteroid kullanımının da faydası gösterilmemiştir $(2,5,20,23)$. Çalışmalarda bronkodilatör kullanım oranları \%25-81; sistemik steroid kullanım oranları (\%8-44) olarak bildirilmiştir (14, 18, 24). Olgularımızın \%99.3'üne salbutamol, \%67.8'ine sistemik steroid, \% 20.4'üne İpratropium bromür ve \%8.8'ine adrenalin verilmişti. Sistemik steroid ve ipratropium bromür orta/ağır bronșiolit olan olgularda daha fazla uygulanmıştı. Bronşiolit tedavisinde kulllanabilecek seçeneklerin az olması, çocuğu rahatlatma intiyacı nedeniyle faydası az olan ilaçlar kullanılmaktadır (2, 14, 24). Kanıta dayalı destek tedavi uygulamasındaki değişiklikler bölgesel, sosyal faktörlere ve klinik tecrübe farklııklarına bağlı olabilir. Ebeveynlerin birşey yapılma beklentisi uygulamaları etkilemektedir (14).

Amerikan pediatri akademisi'nin (AAP) bronşiolit kılavuzu yayınlanmasından önce yapılmış çalışmalarda, acil serviste ve yatan hastalarda tanı testleri ve uygulanan tedavilerde bronşiolit yönetiminde önemli farklılıklar saptanmıştır (25). Akut bronşiolit tanısı klinik olarak konulur. Bakteriyel enfeksiyon veya komplikasyon şüphesinde, tekrarlayan bronşiolitlerde ve ağır klinik bulgularda labaratuar tetkikleri gerekebilmektedir. Çalışmalarda akciğer grafi çekilme oranlarının \% 35-85 olduğu bildirilmiştir $(14,18,24,26)$. Johnson ve ark. (17) bronşiolit yönetimi ile ilgili çalışmalarında AAP klavuzu sonrasında akciğer grafisi kullanımında azalma olduğunu fakat bronkodilatör, kortikosteroid ve antibiyotik kullanımında önemli bir değişiklik olmadığını saptamışlardır. Özellikle Avustralya, Yeni Zelanda, Birleşik Krallık ve İrlanda`da akut bronşiolit olgularında az kaynak kullanıldığı bildirilmiştir (14). Macias ve ark.'nın (24) çok merkezli çalışmalarında; tam kan sayımı istenme oranı \% 21-75; akciğer grafisi çekilme oranı \%21-75; kortikosteroid kullanma oranları \%8-44 ve yatış oranının \%77.7 olduğunu bildirmişlerdir. Çalışmamızda olguların \%76.8'ine akciğer grafisi çekilmişti, \%75.6'sında tam kan sayımı, \%66.3'ünde CRP tetkiki istenmişti. Tekrarlayan bronşioliti olan olgularda daha fazla 
hemogram istenmişti, orta- ağır atak olan olgularda daha fazla tetkik yapılmıştı. Kanıta dayalı kılavuzların yayınlanmasından sonra bronşiolitin yönetiminde istenilen değişikliklerin olmaması, klinik pratiğin değiştirilmesinin zor olmasına bağı olabilir.

Sistemik enfeksiyonlarda (bakteriyel pnömoni, akut pyelonefrit gibi), artmış proinflamatuar sitokinlerin kemik iliğinde trombosit üretimini tetiklediği, trombositlerin büyüklüğünü ve sayısını değiştirdiği bilinmektedir (15). Akut bronşiolit sırasındaki MPV değişikliğini gösteren az sayıda çalışma vardır. Gökçe ve ark.'nın (15) çalsşmasında akut bronşiyolitli bebeklerin MPV'lerinin kontrol grubuna göre önemli ölçüde yüksek olduğu, Ergül ve ark.'nın (7) çalışmasında ise akut bronşiyolitli olgularda MPV'nin sağlıklı çocuklara göre istatistiksel olarak önemli ölçüde düşük olduğunu bildirmiştir. Güzel ve ark.'nın (27) çalışmasında olguların bronşiolit dönemindeki beyaz küre ve MPV değerlerinin kontrol grubundaki olgulara göre daha yüksek olduğu gösterilmiştir. Turhan ve ark., (28) sık bronşiolit geçiren çocuklarda eozinofil sayısının daha yüksek olduğunu saptamışlardır. Tekrarlayan bronşiolitlerde eozinofilik inflamasyonun rol oynadığı düşünülmektedir biz de bu olgularda eozinofil sayısının çalışmalara benzer şekilde daha yüksek olduğunu saptadık. Çalışmamızda sağ|ıkı dönem ile bronşiolit dönemindeki platelet ve MPV değerleri arasında fark saptanmadı, Bronşiolite neden olan virüsün bronşiyal mukoza üzerindeki sitopatik etkisi ve enflamatuar yanıt sadece bronş epitelinde lokalize olduğu için MPV'de değişiklik saptanmamış olabilir.

Akut bronşiyolitin sıklıkla kendi kendini sınırlar ve olguların çoğu acil servisden taburcu edilirler. Çalışmalarda yatış oranları (\%1377) arasında değişmektedir $(3,17,24)$. Literatüre benzer şekilde olgularımızın yatış oranı \%41.7'di. Hastaneye yatış kararı, klinik, sosyal, kültürel ve coğrafi faktörlerden etkilenen karmaşık bir süreç olduğu için farklı yatış oranları olabilir.

Çalışmamızın bazı kısıt|lıkları vardır. Birincisi, tek merkezli ve geriye dönük bir çalışma olmasıdır. Olgular hastane kayıtlarındaki tanı kodlarına göre toplanmıştır. Geriye dönük bir araştırma olduğu için eksik verileri olan olgular çalışmaya alınamamışıı.

\section{SONUÇ}

Akut bronşiolit, süt çocukluğu döneminde acil servis başvurularını ve hastane yatışlarının önemli bir nedenidir. Olguların büyük bölümünde hafif geçirilen, kendini sınılayan bir hastalıktır fakat hastalık şiddetinin belirlenmesi ve hastaların uygun tedaviler ile izlemi önemlidir. Hastalık şiddetinin belirlenmesinde MPV değerinin bir önemi saptanmamıştır. Özellikle tekrarlayan bronşiolit olgularında eozinofil değerinin bakılması, havayolu inflamasyonunun erken saptanması, önlem alabilme açısından anlamlı olabilir. Tedavi yaklaşımlarının belirlenmesi için kontrollü, prospektif çalışmalara intiyaç vardır.

\section{KAYNAKLAR}

1. Cai Z, Lin Y, Liang J. Efficacy of salbutamol in the treatment of infants with bronchiolitis: A meta-analysis of 13 studies. Medicine 2020;99:e18657.

2. Smith DK, Seales S, Budzik C. Respiratory Syncytial Virus Bronchiolitis in Children. American family physician 2017;95:94-9.

3. Fujiogi M, Goto T, Yasunaga H, Fujishiro J, Mansbach JM, Camargo CA, Jr., Hasegawa K. Trends in Bronchiolitis Hospitalizations in the United States: 2000-2016. Pediatrics 2019;144.

4. Meissner HC. Viral Bronchiolitis in Children. N Engl J Med 2016;374:1793-4.

5. National Collaborating Centre for Ws, Children's. Bronchiolitis: Diagnosis and Management of Bronchiolitis in Children. London: National Institute for Health and Care Excellence (UK); 2015 Jun.

6. Yalçın E, Karadağ B, Uzuner N, Yüksel H, Gürkan F, Altındaș DU ve ark. Türk Toraks Derneği Akut Bronșiolit Tanı ve Uzlaşı Raporu. Türk Toraks Dergisi 2009; 10: S1-7.

7. Ergül AB, Torun Y, Uytun S, Aslaner H, Kısaaslan AP, Şerbetçi MC. Akut bronşiolitli çocuklarda ortalama trombosit hacminde azalma. Turk Pediatri Ars 2016;51:40-5.

8. Shemirani AH, Nagy B Jr, Takats AT, Zsori KS, Andras C, Kappelmayer $\mathrm{J}$, et al. Increased mean platelet volume in primary Raynaud's phenomenon. Platelets 2012;23:312-6.

9. Lee IR, Shin JI, Park SJ, Oh JY, Kim JH. Mean platelet volume in young children with urinary tract infection. Sci Rep 2015;5:18072.

10. Karadag-Oncel E, Ozsurekci Y, Kara A, Karahan S, Cengiz AB, Ceyhan M. The value of mean platelet volume in the determination of community acquired pneumonia in children. Ital $\mathrm{J}$ Pediatr 2013;39:16.

11. Renshaw AA, Drago B, Toraya N, Gould EW. Respiratory syncytial virus infection is strongly correlated with decreased mean platelet volume. Int J Infect Dis 2013;17:e678-80.

12. Diagnosis and management of bronchiolitis. Pediatrics 2006;118:1774-93.

13. Çiftel M, Biçer S, Şiraneci R. Çocuklarda Akut Bronşiolit. JOPP Derg 2009;1:115-23.

14. Schuh S, Babl FE, Dalziel SR, Freedman SB, Macias CG, Stephens $D$, et al. Practice Variation in Acute Bronchiolitis: A Pediatric Emergency Research Networks Study. Pediatrics 2017;140.

15. Gokce S, Kurugol Z, Suner A. The role of mean platelet volume in the early detection of acute bronchiolitis: A prospective study. Clin Respir J 2018;12:2513-8.

16. 1Kanık A, Eliaçık K, Koyun B, İnce OT, Derici YK, Yılmaz NÖ ve ark. Viral Etiology of Acute Bronchiolitis in Hospitalized Infants and the Effect on Clinical Course. J Pediatr Inf 2016;10:93-8.

17. Johnson LW, Robles J, Hudgins A, Osburn S, Martin D, Thompson A. Management of bronchiolitis in the emergency department: impact of evidence-based guidelines? Pediatrics 2013;131 Suppl 1:S103-9.

18. Florin TA, Byczkowski T, Ruddy RM, Zorc JJ, Test M, Shah SS. Variation in the management of infants hospitalized for bronchiolitis persists after the 2006 American Academy of Pediatrics bronchiolitis guidelines. J pediatr 2014;165:786-92.e1.

19. Ergin H, Dağdeviren E, Polat A, Kılıç I, Semiz S, Cinbiş M. Akut Bronşiyolitli Olguların Retrospektif Değerlendirilmesi. ADÜ Tıp Fakültesi Dergisi 2005;6:29-32.

20. Ralston SL, Lieberthal AS, Meissner HC. Ralston SL, Lieberthal AS, Meissner HC, et al. Clinical Practice Guideline: The Diagnosis, 
Management, and Prevention of Bronchiolitis. Pediatrics 2014;134:e1474-e1502.

21. Friedman JN, Rieder MJ, Walton JM. Bronchiolitis: Recommendations for diagnosis, monitoring and management of children one to 24 months of age. Paediatr Child Health 2014;19:485-98.

22. National Institute for Health and Care Excellence. Bronchiolitis in children: diagnosis and management. 2015 [cited 2016 June 24]. Available from: https:// www. nice. org. uk/guidance/ ng9.

23. Fernandes RM, Bialy LM, Vandermeer B, Tjosvold L, Plint AC, Patel $\mathrm{H}$, et al. Glucocorticoids for acute viral bronchiolitis in infants and young children. Cochrane Database Syst Rev 2013:Cd004878.

24. Macias CG, Mansbach JM, Fisher ES, Riederer M, Piedra PA, Sullivan AF, et al. Variability in inpatient management of children hospitalized with bronchiolitis. Acad pediatr 2015;15:69-76.
25. Christakis DA, Cowan CA, Garrison MM, Molteni R, Marcuse E, Zerr DM. Variation in inpatient diagnostic testing and management of bronchiolitis. Pediatrics 2005;115:878-84.

26. Plint AC, Johnson DW, Patel H, Wiebe N, Correll R, Brant R, et al. Epinephrine and dexamethasone in children with bronchiolitis. $\mathrm{N}$ Engl J Med 2009;360:2079-89.

27. Güzel EÇ, Fidan Ç, Güzel S, Paketçi C, Çelikkol ÜA. Bronşiyolitli Çocuklarda Hastalık Aktivitesinin Değerlendirilmesinde Nötrofil/ Lenfosit Oranı Yeni bir Biyobelirteç Olabilir mi? Namık Kemal Tıp Dergisi 2019;7:13-8.

28. Turan AH, Arıkoğlu T, Tezol Ö, Aslan G, Kuyucu S. Infantlarda Sık Hışıltı Gelişimini Öngörmede Erken Yaşam Belirteçleri; Gizemli Bir Yolda Eski Dost, "Eozinofil" ile Devam Etmek. Asthma Allergy Immunol 2017;15:1-5. 